\title{
Methods of combating the legalization of proceeds from crime through non-state pension funds
}

\section{I. Tikhon}

Faculty of Risk Analysis and Economic Security named after Professor V.K. Senchagov "Financial University under the Government of the Russian Federation" Moscow, Russia

\section{Abstract}

The crisis in the field of social security of the population occurred in the process of transformation of economic relations, and, first of all, in the pension system. A reform of the pension system has been implementing for a sufficient period of time, in order to overcome the negative phenomena. Non-state pension funds (further NPFs) have been severely criticized by the Ministry of Health and Social Development to address

Corresponding Author: V. I. Tikhon

Viktoriya1580@mail.ru

Received: 11 December 2017

Accepted: 20 January 2018

Published: 13 February 2018

Publishing services provided by Knowledge $\mathrm{E}$

(c) V. I. Tikhon. This article is distributed under the terms of the Creative Commons

Attribution License, which permits unrestricted use and redistribution provided that the original author and source are credited.

Selection and Peer-review under the responsibility of the FinTech and RegTech: Possibilities, Threats and Risks of Financial Technologies Conference Committee. the mandatory pension insurance system. Private organizations ineffectively manage the pension savings of citizens, and there is also a place for - the legalization of criminal proceeds, the ministry believes, which can be confirmed by the data published by the Bank of Russia on the revocation of licenses from a number of NPFs (Informationanalytical materials. Review of the main indicators of non-state pension funds // https://www.cbr.ru/finmarkets/files/supervision/review_npf_040716.pdf).

The legalization of criminal proceeds is by itself a very negative phenomenon, which adversely affects the individual organization, the economy as a whole and social life, exerting a detrimental effect on the economic and national security of society and the state. Operations, to some extent related to the legalization of criminal proceeds, significantly increase the risk of loss of reputation for non-state pension funds. As a result, these monetary resources fall into the global financial system, and acquire the ability to undermine the national currency and the economies of individual countries, thus creating a threat to both national and international security.

Keywords: Legalization of criminal proceeds, private pension funds, risk-oriented approach, internal control.

\section{Introduction}

Security and recoverability are the conditions for the implementation of investment rules for the management company, which is represented by the counterparty of the fund. Non-state pension funds independently deal with their customers, as they are 
transferred financial results under a trust management agreement. Thus, there is a conflict of interests between the NPF and the management company that is focused on financial growth, due to the fact that its profits will be declared, but if under the trust management agreement the fund has a loss, then all responsibility falls on the NPF itself, and not the management company.

According to the Russian legislation, "laundering of money obtained by criminal means giving a legitimate form of possession, use and disposal of funds or other property obtained as a result of the commission of a crime". (The Law of the Russian Federation "On Counteracting the Legalization (Laundering) of Proceeds from Crime and Financing of Terrorism" of 07.08.2001 No. 115 // Collected Legislation of the Russian Federation. with changes. and add. in Ed. as of July 29, 2017)

The creation of a highly effective national system to counter money laundering is one of the most acute and pressing problems.

The effectiveness of the entire AML / CFT system is built on the effectiveness of all its elements, in particular directly in organizations that are the smallest structural units of the AML / CFT system. As already mentioned, the main role in anti-money laundering activities in organizations is played by the internal control system.

Despite the fact that the internal control system of each individual organization is unique in its own way, internal control for AML / CFT purposes is based on the following principles that are typical for any company.

1. The principle of responsibility;

2. The principle of balance;

3. The principle of integration;

4. The principle of interest;

5. The principle of conformity;

6. The priority principle;

7. The principle of complexity;

8. The principle of the regulations.

The importance of introducing internal control is conditioned by the fact that, the revenue part of non-state pension funds consists not only of the receipt of the funded portion of pension contributions, but also of the investment activity to which the received funds are directed (Fig. 1).

The structure of investments in pension accumulations of NPFs is quite stable - the main volume of investments falls on corporate bonds. However, in the first quarter of 2016 , the share of this direction of investment decreased, the change is due to the 


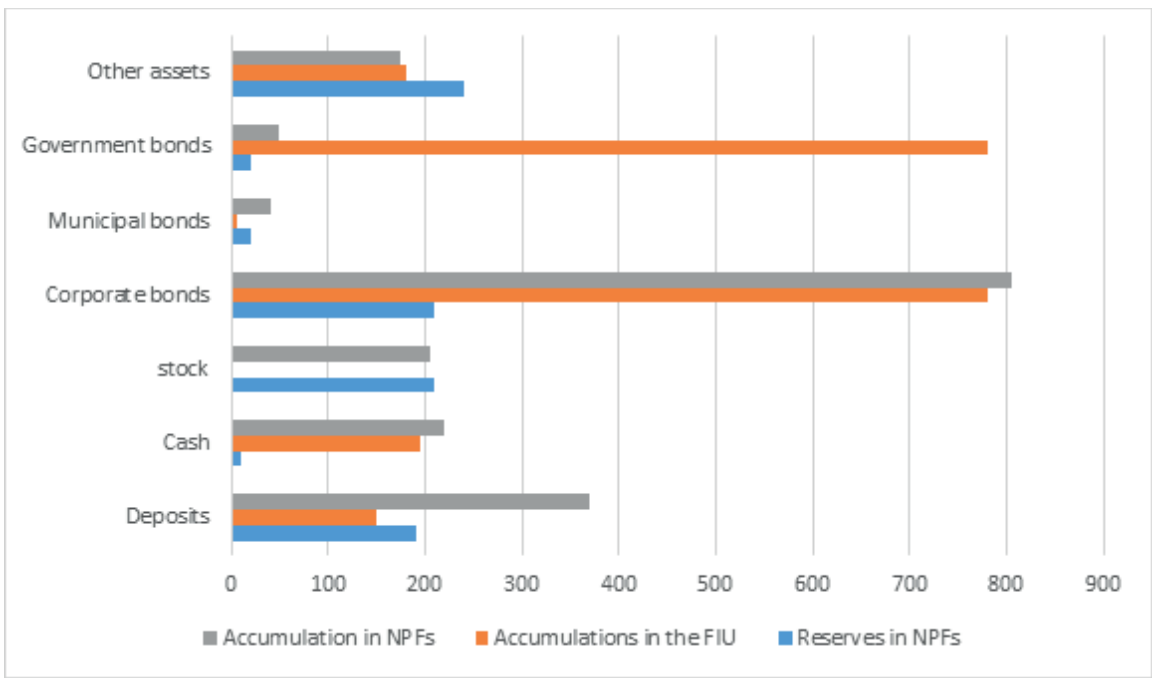

Figure 1: The structure of placement of pension funds in Russian pension funds in 2016. Source: Bank of Russia.

growth of funds on current accounts, where obtained money were received from the FIU. Thus, the share of funds on current accounts for three months of 2016 increased from $4.4 \%$ to $13.7 \%$, another $12.1 \%$ of the portfolio is attributable to equity investments. At the same time, a significant part of investments in securities falls on shares and bonds of banks and financial institutions, which ultimately increases the cost of pension funds for the real sector.

The main changes in the structure of the pension accumulation portfolio of the FIU are also related to the transfer of funds to NPFs, the most significant decrease was the share of bank deposits from $16.5 \%$ to $3.3 \%$. Investments in government securities of the Russian Federation at the end of the first quarter of 2016 are $40.6 \%$, in corporate bonds - $38.9 \%$. During the first three months of 2016 , pension funds managed to show a profitability above inflation, which was promoted by the dynamics of the stock market.

Thus, internal control in the NPF sector is a certain guarantor of compliance with AML / CFT legal requirements, and also favors anti-money laundering activities, being a key element of the national AML / CFT system. The organization's internal control rules allow it to formalize many processes, including those related to the AML / CFT sphere, thereby allowing for more effective work on risk management.

In order to assess the results of the state efforts to minimize the risk of conducting doubtful money laundering operations, one can use the reliability rating of the NPF, which was made by the rating agency Expert RA (Table 1). Currently, according to the methodology, the factors that can influence the degree of NPF reliability are: market positions, financial analysis, management and risk management. 
TABLE 1: Reliability rating NPF.

\begin{tabular}{|c|c|c|c|c|}
\hline Name & Rating & $\begin{array}{l}\text { Total amount of } \\
\text { pension reserves } \\
\text { (thousand rubles) }\end{array}$ & $\begin{array}{c}\text { Number of } \\
\text { participants in } \\
\text { NPFs } \\
\text { (individuals) }\end{array}$ & Profitability \\
\hline $\begin{array}{l}\text { JSC "NPF" } \\
\text { NEFTEGARANT" }\end{array}$ & rUAA & $3,587,900$ & 76,808 & $8,71 \%$ \\
\hline JSC "NPF Soglasie" & ruA+ & $71,600,000,000$ & $1,100,000$ & $8,92 \%$ \\
\hline Atomgarant & rUAA & $4,133,400$ & 57,452 & $7.3 \%$ \\
\hline NPF Blagosostoianie & rUAAA & $95,052,200$ & 1418649 & 11,15 \\
\hline $\begin{array}{l}\text { Pension Fund VTB } \\
\text { Pension Fund }\end{array}$ & rUAAA & $124,050,706,500$ & $1,302,453$ & $13,25 \%$ \\
\hline Doverie & ruBBB- & $33,600,000,000$ & 882,993 & $8,3 \%$ \\
\hline National Pension Fund & rUAA & $11,569,600$ & 317,043 & $10.78 \%$ \\
\hline $\begin{array}{l}\text { NPF GAZFOND } \\
\text { pension savings }\end{array}$ & rUAAA & $425,636,643,000$ & $6,100,000$ & $13,16 \%$ \\
\hline NPF RGS & rUBBB+ & $49,862,700$ & $1,416,275$ & $11.4 \%$ \\
\hline NPF Sberbank & rUAAA & $74,247,100,000$ & $1,059,296$ & $8,84 \%$ \\
\hline SPC "Social life" & ruAA- & $14,116,608$ & 386,069 & $8.53 \%$ \\
\hline Khanty-Mansiysk NPF & ruA- & $13,660,000,000$ & 390,000 & $9,47 \%$ \\
\hline
\end{tabular}

The table shows some of the most reliable non-government pension funds, but you can see that some of them are joint-stock companies and do not focus on increasing the number of clients, but work exclusively for their employees. The other part, on the contrary, is interested in increasing the number of clients, as the total amount of pension reserves increases. The presented rating can be considered reliable as the rating consists of two basic things:

1. External Support Factors and Stress Factors

2. Rating of independent reliability

2.1. Internal Support Factors and Stress Factors

2.2. Market positions

2.3. The financial analysis

2.4. Management and Risk Management

As can be seen from Table 2, the total number of personal accounts registered in the pension insurance system from 2014 to 2016 was tended to increase, while the 
TABLE 2: The distribution of the number of personal accounts in the pension fund and in NPFs.

\begin{tabular}{|c|c|c|c|}
\hline & 2016 & 2015 & 2014 \\
\hline $\begin{array}{l}\text { The number of individual personal } \\
\text { accounts of citizens registered in the } \\
\text { mandatory pension insurance system }\end{array}$ & 152212458 & 149695511 & 145187436 \\
\hline $\begin{array}{l}\text { The number of insured persons and the } \\
\text { means of their pension savings } \\
\text { transferred to non-state pension funds } \\
\text { and management companies }\end{array}$ & 46097623 & 53173330 & 51952477 \\
\hline $\begin{array}{l}\text { The share of the number of insured } \\
\text { persons and pension savings transferred } \\
\text { to non-state pension funds and } \\
\text { management companies }\end{array}$ & $23,24 \%$ & $26,21 \%$ & $26,35 \%$ \\
\hline
\end{tabular}

number of personal accounts in APF was decreasing year by year (this trend can be seen if we calculate the proportion of registered individuals in APFs to the total number of citizens).

This fact is connected with the distrust of citizens to be serviced in private pension funds, which further undermines the confidence in NPFs.

Currently, for non-credit financial institutions operating long-term plans, issues related to internal control for AML / CFT purposes have grown into a class of collective strategic interests, ceasing to be an exclusively internal matter of the organization.

The basis for the successful performance of financial monitoring functions in organizations that perform tens and hundreds of thousands of transactions every day is the introduction of an internal control model for AML / CFT purposes, which is based on the principle of a risk-based approach.

The essence of the risk-oriented approach lies in the fact that planning for internal control works is organized in predetermined areas of significant risk.

The operation of the risk-based approach is based on minimizing the various risks in the organization's activities and increasing the reliability of the fact that the goals set by the enterprise will be achieved.

The key objective in implementing the risk-oriented approach is to optimize various types of costs (monetary, labor, temporary) for performing functions related to financial monitoring in the organization, without reducing the quality of AML / CFT activities. 
Failure to demonstrate sufficient compliance with regulatory requirements can lead to severe criticism on the part of the regulator, the use of conditional sanctions, significant fines, the introduction of independent supervisory authorities on the actions of management, and also cause damage to reputation.

In particular, there may be suspicions in NPFs that customer transactions are being carried out for the purpose of laundering proceeds from crime, which means that there is a problem of ineffective monitoring of operations.

An immediate consequence of this problem is the untimely identification of questionable transactions or their failure to identify can lead to untimely application or non-application of measures that are aimed at their suppression. Moreover, individual units may accidentally or intentionally establish relations with suspicious customers, while the right or requirement of legislation to refuse to open an account has not been used or deliberately not executed.

It is also necessary to take into account the fact that not only NPF clients, but also the fund itself, can be engaged in activities to legalize the proceeds of crime, for example investing the activities of companies that are engaged in criminal activities.

When making decisions, many risks are not taken into account, or underestimated, while other risks are overestimated, because decision makers do not have an objective picture of the existing risks and instruments for measuring them.

Objective impossibility of formation of ideal models for schemes and maps for risk assessment, also due to their obsolescence, changes and attraction of new performers of labor functions, as well as the need for constant verification, revision, modernization of such forms. This leads to additional waste of time and human resources.

\section{Methods for improving the internal control system}

Like any other system, the internal control system has its own development directions, focused on eliminating shortcomings and vulnerabilities. The introduction of a riskoriented approach into the practice of internal control for AML / CFT purposes has yielded significant positive results in the form of savings in labor, time, money and other resources. Despite obvious advantages, there are also disadvantages. Moreover, it is practically impossible or essential to economically disadvantageously and inexpediently to impose on certain shortcomings in objectively existing conditions of reality, while other negative phenomena can be completely leveled out.

And it is guided by the latter that we will propose improvements to the internal control system for AML / CFT purposes. 
Regulation of business processes. In order to properly implement internal antilegalization procedures, the organization should develop regulations that describe the order of interaction, the areas of responsibility and the functions of each of the units.

In the organization, software modules should be used to automate certain work areas in order to reduce labor costs B within the framework of implementation of certain anti-legalization procedures, as well as to take into account the operational risk $B$ of the AML / CFT area due to the human factor.

Competence of the staff. Employees of the organizational units are required to have special knowledge, skills, skills as subjects of the system of internal control over the legalization of criminal proceeds.

The tendency of the outflow of AML / CFT specialists, formed as a result of the tightening of administrative sanctions, may well be suspended by making adjustments in paragraph 1 and paragraph 2 of Art. 15. 27 Code of Administrative Offenses, which provide the cancellation of administrative fines to officials due to the assumption of violations of the so-called "technical" nature (trite because of inattention). We believe that in such situations the management of the organization must make an informed decision about the use of penalties to such persons and at the same time independently. (S.E. Kovaleva Types of Risks of Credit Organizations in the Sphere of Countering the Legalization of Proceeds from Crime and the Features of their Management in Russian Banking Practice // Management of Economic Systems. -2013 - №9)

Compliance with these procedures is the basis for the effective functioning of the internal control system for AML / CFT purposes in the organization. We also note one more important component of the financial monitoring mechanism, which is a local legal basis for the functioning of the organization, i.e. rules of internal control, which include the procedure for the organization of anti-legalization procedures and a full range of measures used to protect the organization from unreliable and dubious clients. Strict compliance with the rules of internal control is mandatory for all employees.

\section{Conclusions}

Thus, improving the risk management of financial organizations in the field of combating the legalization of proceeds from crime requires an integrated and systematic approach, which must be implemented simultaneously both at the intra-corporate level and at the level of public administration. The identification and implementation of proposed measures in the Russian practice will not only significantly reduce the impact of external and internal risk factors of organizations in the sphere of combating 
the legalization of proceeds from crime by their activities. It is also able to improve the efficiency of the financial sector within the national AML / CFT system, bringing its basic characteristics closer to international best practices.

\section{References}

[1] The Law of the Russian Federation on August 7, 2001 No. 115 "On countering the legalization (laundering) of proceeds, in a robbery manner, and the financing of terrorism"

[2] Order of Rosfinmonitoring No. 59 dated 17.02.2011 "On approval of the Regulation on requirements for identification of customers and beneficiaries, including, taking into account the degree (level) of risk of the client committing operations for money laundering, to penalties";

[3] Regulation No. 445-P of the Bank of Russia of December 15, 2014 "On Requirements for Internal Control Rules of Non-Credit Financial Organizations for the Purpose of Countering the Legalization (Laundering) of Proceeds, Criminally Lined, and Financing Terrorism";

[4] Informational letter of Rosfinmonitoring dated 02.08.2011 No. 17 "On the signs of operations, types and conditions of activity, to the increased risk of clients for the purpose of legalization (laundering) of incomes, levels by criminal means, and financing of terrorism";

[5] Internal control: the methodology of end-to-end monitoring of autonomous institutions: Monograph / A.V. Porfiryeva, T.Yu. Serebryakov. - M.: SIC INFRA-M, 2016. $-152 \mathrm{C}$

[6] Monitoring tools: Monograph / V. Ya. Vilisov, IE Sukov - M.: IC RIOR, SIC INFRA-M, 2016. - 262 p.

[7] Kondrat E.N. Offenses in the financial sphere of Russia. Threats to financial security and ways of counteraction. M.: FORUM, 2014. - 928 p.

[8] International financial security in the context of globalization. Basic directions. law enforcement. cooperation of the state-in: Monogr. / E.N. Kondrat. - 3rd ed., Pererab. and additional. - M.: ID FORUM, 2013. - $592 \mathrm{~S}$

[9] Kovaleva S.E. Types of management of credit organizations in the sphere of combating money laundering, finance and their management in Russian banking practice // Management of economic systems. -2013 - \#9 
[10] Legal regulation of financial control in the Russian Federation: problems and prospects: Monogr. / L.L. Arzumanova, O.V. Boltinova, O.Yu.Bubnov; Otv. Ed. E.Yu.Gracheva. - M.: Норма: M, 2015. - 384 C.

[11] Risks of economic entities: theoretical bases, methodologies for analysis, forecasting and management: Method.. / V.I. Avdysky, V.M. Bezdenezhnykh. -M.: Alpha-M: SIC INFRA-M, 2013 - 368 p.

[12] Information and analytical materials. Review of the main indicators of non-state pension funds // https://www.cbr.ru/finmarkets/files/supervision/review_ npf_040716.pdf 